\title{
Analytical Determination of Uranium (VI) by Spectrophotometry
}

\author{
V.Veeranna*, M.V.V.Vara Prasad**, Anand Jonnadula*** \\ Department of Chemistry, AMC Engineering College, Karnataka, \\ Sri Krishnadevaraya University, Anantapur, A.P., India \\ *saidikshav@gmail.com
}

\begin{abstract}
A new reagent namely 3,4-Dihydroxybenzaldehyde Thiosemicarbazone (3,4-DHBTSC) synthesized by the authors for the determination of uranium(VI) in monazite sand, pitchblend ore, spiked water, human hair and human blood samples. A brown colored complex was formed between uranium(VI) and 3,4-DHBTSC in a media of $\mathrm{pH}$ 7. The developed method can be conveniently applied for the analytical determination of uranium (VI) in the concentration range $0.476-4.760 \mu \mathrm{g} / \mathrm{ml}$. The molar absorptivity and sandell's sensitivity were found to be $2.0833 \times 10^{4} \mathrm{~L} / \mathrm{mol} / \mathrm{cm}$ and $0.0114 \mu \mathrm{g} / \mathrm{cm}^{2}$ respectively. The proposed method was found to be linear $(R>0.01)$, selective, accurate (recovery $=<99.7 \%)$ and precise $(R S D<1.1 \%)$ in the reported linear calibration line.
\end{abstract}

Keywords: 3,4-DHBTSC; Spectrophotometry; Uranium(VI); Spiked water sample.

\section{INTRODUCTION}

Uranium and its compounds are highly toxic. Exposure to elemental uranium and all of its inorganic compounds can cause cancer and acute respiratory illness. Though they are toxic, they have been widely used in medicinal, ceramic, glass, electrolytic and electrical appliances industries. Releasing of uranium into the environment is inexorable as the compounds of uranium are highly reactive, volatile and soluble in water. Hence there is a need, and has been a growing interest to develop the analytical procedures for the micro gram determination of uranium.

\section{EXPERIMENTAL}

The buffer solutions were prepared as follows;

pH 1.0 to 3.0: By mixing hydrochloric acid and sodium acetate.

pH 3.5 to 7.0: Acetic acid and sodium acetate.

pH 8.0 to 12.0: Ammonium chloride and ammonium hydroxide.

All solvents and chemicals used were of analytical reagent grade. By appropriate dilutions of the stock solution the working solutions were prepared. For the preparation of solutions double-distilled water was used.

Table1. A comparison to show the merits of the reported method

\begin{tabular}{|l|l|l|l|l|}
\hline S.NO. & \multicolumn{1}{|c|}{ Method } & \multicolumn{1}{|c|}{$\begin{array}{c}\text { Detection } \\
\text { limit }\end{array}$} & \multicolumn{1}{|c|}{ Remark } & Ref.No. \\
\hline 1 & $\begin{array}{l}\text { Spectrophotometric determination of } \\
\text { uranium(VI) via complexation with } \\
\text { prioxicam }\end{array}$ & $0.094 \mu \mathrm{g} / \mathrm{ml}$ & $\begin{array}{l}\text { Though it is sensitive but } \\
\text { not selective }\end{array}$ & 1 \\
\hline 2 & $\begin{array}{l}\text { Spectrophotometric determination of } \\
\text { uranium(VI) with pyrocatechol violet } \\
\text { in surfactant media }\end{array}$ & $0.15 \mu \mathrm{g} / \mathrm{ml}$ & $\begin{array}{l}\text { Though it is simple and } \\
\text { sensitive but not selective }\end{array}$ & 2 \\
\hline 3 & $\begin{array}{l}\text { Spectrophotometric determination of } \\
\text { uranium(VI) by extraction with } \\
\text { tropolone }\end{array}$ & $\begin{array}{l}\text { A comparative analysis of uranium levels } \\
\text { ore using laser fluorimetric and } \\
\text { gamma spectrophotometry } \\
\text { techniques }\end{array}$ & $\begin{array}{l}\text { Involves } \\
\text { preconcentration and } \\
\text { extraction steps }\end{array}$ & 3 \\
\hline 4 & $\begin{array}{l}\text { Involves complicated } \\
\text { procedure, not sensitive } \\
\text { and selective }\end{array}$ & 4 \\
\hline
\end{tabular}




\begin{tabular}{|c|c|c|c|c|}
\hline 5 & $\begin{array}{l}\text { Solvent extraction studies of } \\
\text { uranium(VI) from aqueous media into } \\
\text { Chloroform Solution of } N, N^{\prime}- \\
\text { ethylenebis(4-propionyl-2,4-dihydro- } \\
\text { 5- methyl-2-phenyl 3H-pyrazol-3- } \\
\text { oneimine) }\end{array}$ & Microgram levels & $\begin{array}{l}\text { Involves separation and } \\
\text { preconcentration steps }\end{array}$ & 5 \\
\hline 6 & $\begin{array}{l}\text { Accurate determination of uranium in } \\
\text { Soils using electroplating and closed } \\
\text { vessels microwave digestion methods }\end{array}$ & $\begin{array}{l}\text { Microgram } \\
\text { levels/kg }\end{array}$ & $\begin{array}{l}\text { Time consumption } \\
\text { method, low yield and } \\
\text { recovery }\end{array}$ & 6 \\
\hline 7 & $\begin{array}{l}\text { Determination of depleted uranium } \\
\text { using a high-resolution gamma-ray } \\
\text { spectrometer and its applications in } \\
\text { soil and sediments }\end{array}$ & 15.97 Becquerel/kg & $\begin{array}{l}\text { Involves complicated, } \\
\text { tedious steps and also } \\
\text { preconcentration steps }\end{array}$ & 7 \\
\hline 8 & $\begin{array}{l}\text { Determination of uranium isotopes in } \\
\text { soil samples by coprecipitation }\end{array}$ & $5.88 \mathrm{mg} / \mathrm{kg}$ & $\begin{array}{l}\text { Lack of accuracy and } \\
\text { foreign ions may effect in } \\
\text { the determination }\end{array}$ & 8 \\
\hline 9 & $\begin{array}{l}\text { Determination of uranium contents in } \\
\text { the soils }\end{array}$ & $13 \mathrm{~Bq} / \mathrm{kg}$ & $\begin{array}{l}\text { Proper analytical } \\
\text { parameters had not been } \\
\text { fixed }\end{array}$ & 9 \\
\hline 10 & $\begin{array}{l}\text { Solvent extraction } \\
\text { spectrophotometric determination of } \\
\text { uranium(VI) using phenylene } \\
\text { bisphenol as an analytical reagent }\end{array}$ & $10.0 \mathrm{ppm}$ & $\begin{array}{l}\text { The stability of the } \\
\text { complex compound is } \\
\text { low }\end{array}$ & 10 \\
\hline 11 & $\begin{array}{l}\text { Spectrophotometric determination of } \\
\text { uranium(VI) using 2-(2- } \\
\text { Thiazolylazo)-p-cresol in the presence } \\
\text { of surfactants }\end{array}$ & $26 \mathrm{ng} / \mathrm{ml}$ & & 11 \\
\hline 12 & $\begin{array}{l}\text { Speciation and spectrophotometric } \\
\text { determination of uranium in seawater }\end{array}$ & Microgram levels & $\begin{array}{l}\text { Involves extraction and } \\
\text { preconcentration steps }\end{array}$ & 12 \\
\hline 13 & $\begin{array}{l}\text { Spectrophotometric determination of } \\
\text { uranium in bacterial leach liquors } \\
\text { using arsenazo-III }\end{array}$ & $6 \mu \mathrm{g} / 1$ & $\begin{array}{l}\text { Involves } \\
\text { preconcentration steps }\end{array}$ & 13 \\
\hline 14 & $\begin{array}{l}\text { Determination of uranium by } \\
\text { fluorescence method }\end{array}$ & $0.05 \mathrm{ppm}$ & $\begin{array}{l}\text { Complicated and require } \\
\text { skilled analysts }\end{array}$ & 14 \\
\hline 15 & $\begin{array}{l}\text { Determination of uranium in tap water } \\
\text { by ICP-MS }\end{array}$ & $2 \mathrm{ng} / \mathrm{L}$ & & 15 \\
\hline 16 & $\begin{array}{l}\text { Determination of uranium in seawater } \\
\text { samples by liquid chromatography } \\
\text { using mandelic acid as a complexing } \\
\text { agent }\end{array}$ & $500 \mathrm{ppb}$ & & 16 \\
\hline
\end{tabular}

In order to develop a new method for the determination of uranium(VI) as very few methods are available which do not require expensive instrumentation and do not involve extraction and preconcentration steps [17]. The authors have reported a simple, sensitive and selective method for the determination of uranium(VI). The reported method is based on the chromogenic reaction between $\mathrm{U}(\mathrm{VI})$ and 3,4-DHBTSC to give a brown colored complex which has absorption maximum at $370 \mathrm{~nm}$.

Required amount of uranium trioxide was taken in $100 \mathrm{ml}$ standard flask. The salt was dissolved in distilled water and was diluted to $100 \mathrm{ml}$. This serves as a stock solution of uranium(VI).

A Shimadzu UV-visible spectrophotometer (Model UV-160A) equipped with $1 \mathrm{~cm}$ matched quartz cells was used for the measurement of absorbance. An Elico digital $\mathrm{pH}$ meter was used for $p \mathrm{H}$ measurements.

\subsection{Synthesis of 3,4-dihydroxybenzaldehyde Thiosemicarbazone}

3,4-dihydroxybenzaldehyde and thiosemicarbazide dissolved in methanol medium were refluxed for 3 hours. The contents were cooled to room temperature. The pale yellow colored product obtained was separated by filtration. The product obtained was washed with hot water and 50 percent methanol. The product was recrystallised twice from boiling methanol and dried in vacuum. 3,4-DHBTSC solution of concentration $0.01 \mathrm{M}$ prepared in dimethyl formamide serves as a stock solution. 


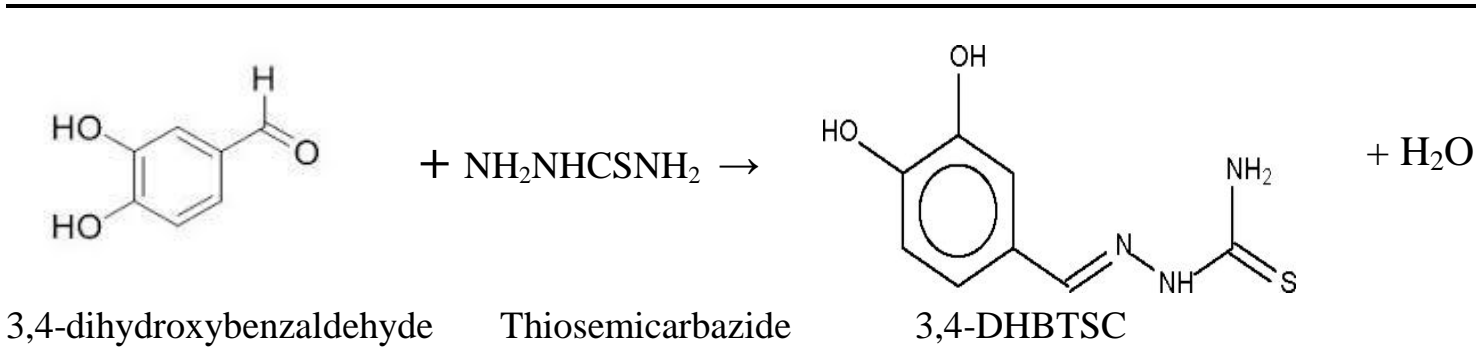

Fig.1 Synthesis of 3, 4-dihydroxybenzaldehyde thiosemicarbazone

The melting point of 3,4-DHBTSC is $221-223^{\circ} \mathrm{C}$, Yield $=9.85 \mathrm{gm}, \%$ of yield $=84.9 \%$.

The structure of the reagent has been established based on IR, Mass and NMR spectra.

\subsection{General Experimental Procedure}

In a $10 \mathrm{ml}$ volumetric flask, $5 \mathrm{ml}$ of buffer solution of required $p \mathrm{H}, 1 \mathrm{ml}$ of uranium trioxide of required concentration and $1 \mathrm{ml} \mathrm{3,4-DHBTSC}$ of required concentration were taken. The contents of the flask were made up to the mark, shaken well and absorption spectrum was recorded against reagent blank.

\section{RESULTS AND DISCUSSION}

\subsection{Effect of pH on Absorbance}

The effect of $\mathrm{pH}$ on the absorbance of the complexation reaction is studied and shown in the Fig.2. The figure gives the information that there is no complex formation between the U(VI) and 3,4DHBTSC in the acidic media ( $p \mathrm{H} 1$ to 4 ), the absorbance increases and gives a maximum at $p \mathrm{H} 7$ and there is a decrease in the absorbance with the further increase in $p \mathrm{H}$. Keeping in view the reproducibility of the complexation between metal \& reagent and stability of the spectrum, a $p \mathrm{H}$ of 7 was considered optimum for further detailed investigation. The absorption spectra showed the maximum absorbance at $370 \mathrm{~nm}$ and this fact was further depicted by the Fig. 3 which showed that complex formed between metal and reagent was responsible for the absorption spectra.

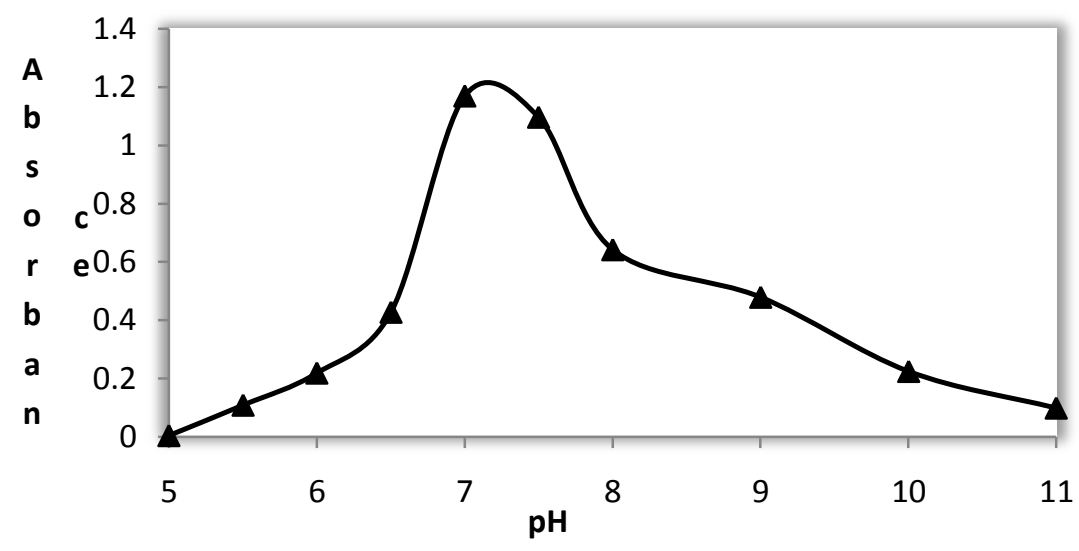

Fig.2 Effect of pH on Absorbance

$$
[U(V I)]=8 \times 10^{-5} \mathrm{M}, \quad[3,4-\mathrm{DHBTSC}]=8 \times 10^{-4} \mathrm{M}, \quad \lambda_{\max }=370 \mathrm{~nm} ;
$$

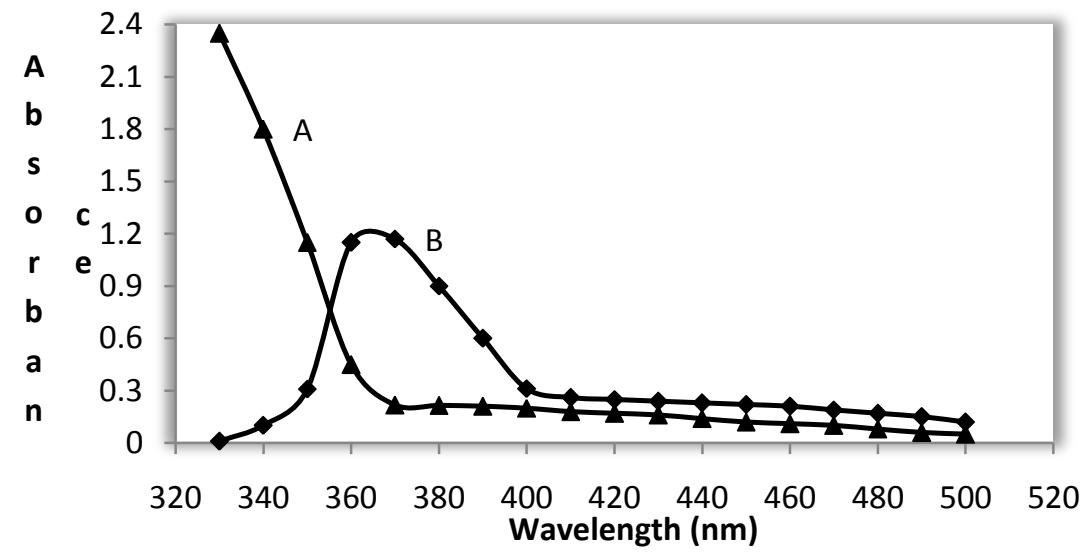

Fig.3 Absorption Spectrum of 
A) 3,4-DHBTSC against the buffer blank. [3,4-DHBTSC] $=8 \times 10^{-3} \mathrm{M}, \quad p H=7$;

B) $U(V I)-3,4-D H B T S C$ complex against the reagent blank. $[U(V I)]=8 \times 10^{-5} \mathrm{M}$,

$[3,4-D H B T S C]=8 \times 10^{-3} \mathrm{M}, \mathrm{pH}=7$;

\subsection{Effect of Reagent (3,4-DHBTSC) on Absorbance}

The absorbance of the solutions containing fixed concentration of metal ion and varying concentration of 3,4-DHBTSC was recorded in a media of $p \mathrm{H} \mathrm{7,} \mathrm{in} \mathrm{order} \mathrm{to} \mathrm{fix} \mathrm{the} \mathrm{concentration} \mathrm{of} \mathrm{3,4-DHBTSC.}$ It was found that an optimum reagent concentration of 15 fold was sufficient for the formation of complex. The addition of excess of the reagent to the metal ion solution does not alter the absorbance of the complexation reaction.

\subsection{Effect of Time on the Complexation Reaction}

Effect of time on the color reaction was studied by measuring the absorbance values of the solution containing fixed amount of $\mathrm{U}(\mathrm{VI})$ at regular intervals of 10 minutes. It was found that the color formation of the complex was instantaneous and absorbance remained constant for more than an hour. This reveals that the complexation between the metal and reagent was stable for a reasonable period of time.

\subsection{Stoichiometric Determination of the Complex}

In order to fix the composition between U(VI) and 3,4-DHBTSC, Job`s method continuous variation and molar ratio methods were employed. In Job's continuous variation method [18], a series of solutions containing required concentration of 3,4-DHBTSC and varying concentration of the metal ion were taken in a $10 \mathrm{ml}$ volumetric flask. The absorbance values of these solutions were measured in each case against the suitable reagent blank and the data is represented in the Fig. 4. The figure reveals that uranium forms 1:1 complex with the reagent. The stability constant of the complex was found to be $3.29 \times 10^{7}$. The stoichiometry of the complex was further confirmed by mole ratio method. In mole ratio method, absorbance of the solutions containing fixed concentration of metal and varying concentration of the reagent was recorded at $370 \mathrm{~nm}$. Both the methods showed that there was 1:1 complex between the metal and reagent.

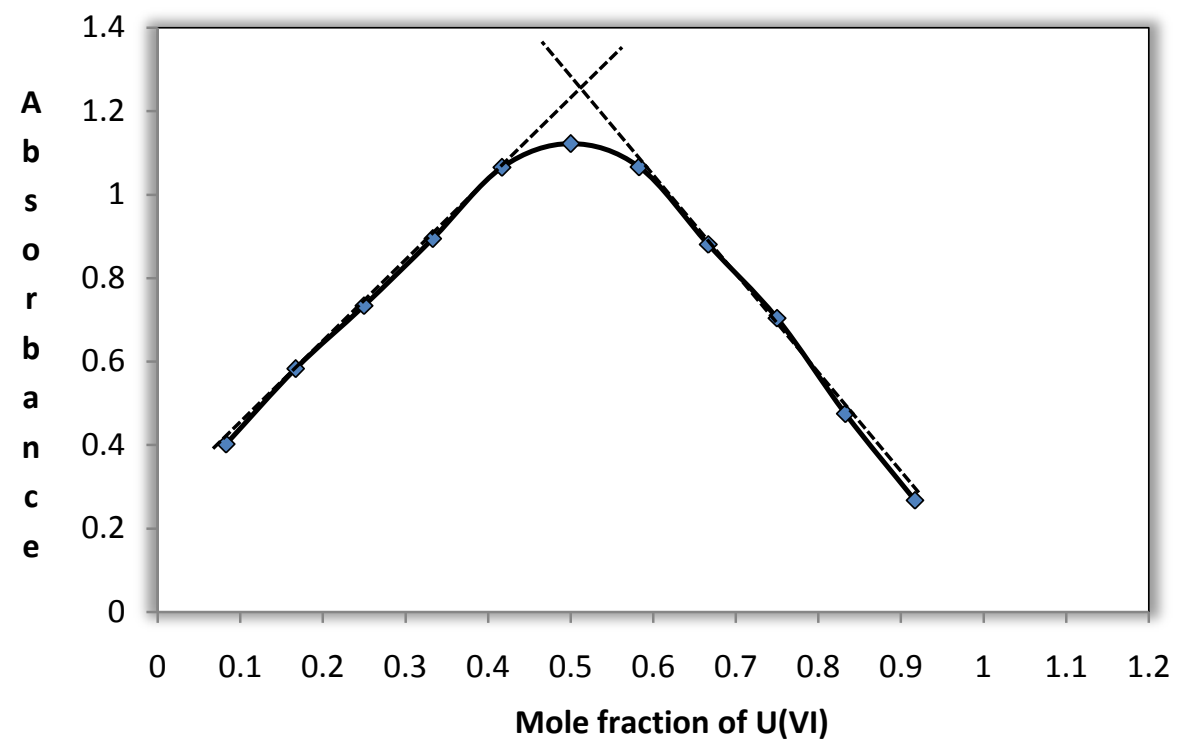

Fig.4Stoichiometry of the complex by Job`s method continuous variation

$$
[3,4-D H B T S C]=[U(V I)]=2 \times 10^{-4} M, p H=7, \lambda_{\max }=370 \mathrm{~nm} ;
$$

\subsection{Analytical determination of $U(V I)$}

In order to estimate the micro gram levels of $\mathrm{U}(\mathrm{VI})$, a series of solutions containing varying concentration of metal ion and fixed concentration of the reagent in the appropriate $p \mathrm{H}$ media was prepared, the absorbance values were measured in each case at $370 \mathrm{~nm}$ against the respective reagent blank solution. Linear calibration graph shown in the Fig. 5 reveals that uranium(VI) can be determined in the linear concentration range $0.476-4.760 \mu \mathrm{g} / \mathrm{ml}$. 


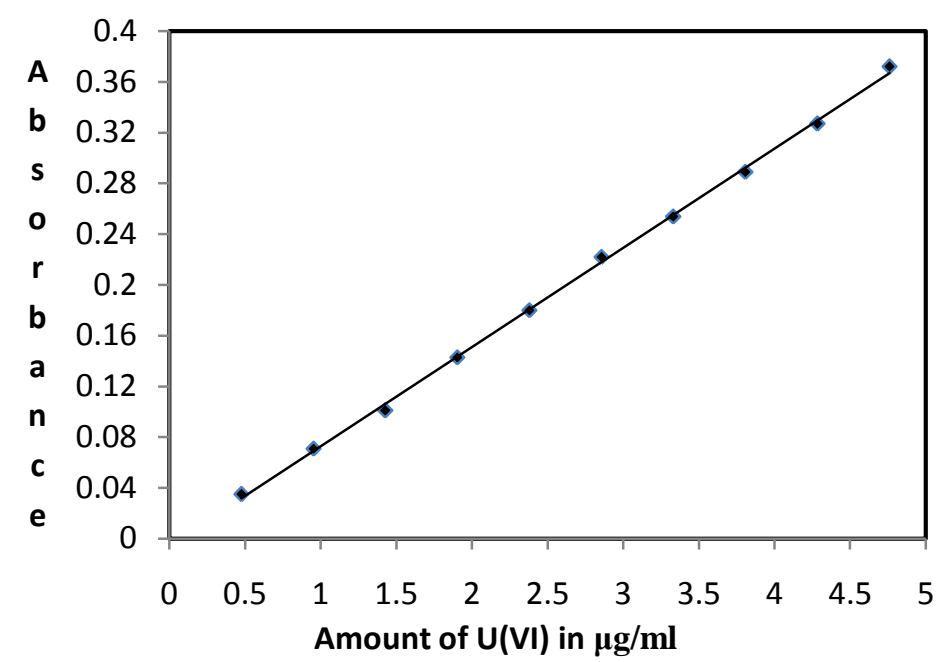

Fig.5 Analytical determination of $U(V I)$

$$
[3,4-D H B T S C]=1.5 \times 10^{-4} M, p H=7, \lambda_{\max }=370 \mathrm{~nm} ;
$$

\subsection{Fixation of Analytical Parameters and Sensitivity}

The linear calibration graph for the analytical estimation of uranium(VI) can be fitted into the formulae $\mathrm{A}_{370 \mathrm{~nm}}=0.0781 \mathrm{C}-0.005$ ( $\mathrm{A}$ is absorbance and $\mathrm{C}$ is concentration in $\mu \mathrm{g} / \mathrm{ml}$ ). The correlation coefficient was found to be 0.9995 . The molar absorptivity and Sandell's sensitivity were $2.0833 \times 10^{4}$ $\mathrm{L} \mathrm{mol}^{-1} \mathrm{~cm}^{-1}$ and $0.0114 \mu \mathrm{g} \mathrm{cm}{ }^{-2}$ respectively. The relative standard deviation (RSD) was found to be around $8.276 \%$. The corresponding method limit of detection (LOD) and limit of quantification (LOQ) were found to be 0.1528 and $0.4632 \mu \mathrm{g} / \mathrm{ml}$ respectively.

\subsection{Effect of Foreign Ions in the Determination}

The effect of diverse ions in the determination of uranium(VI) was carried out by adding a known concentration of foreign ion to a solution containing $4.76 \mu \mathrm{g} / \mathrm{ml}$ of $\mathrm{U}(\mathrm{VI})$ and determining the absorbance latter by the procedure mentioned in 2.2. The tolerance limit of each ion was taken as the concentration of foreign ion which caused less than $\pm 4 \%$ error in absorbance value. It is evident from Table 2 that most of anions and cations did not interfere in the determination. Tolerance limit of $\mathrm{Mo}(\mathrm{VI})$ could be increased up to $175 \mu \mathrm{g} / \mathrm{ml}$ in presence of phosphate as masking agent, while the interference of $\mathrm{Cr}(\mathrm{VI})$ and $\mathrm{Cu}$ (II) can be avoided by masking with $200 \mathrm{ppm}$ of tartrate and $400 \mathrm{ppm}$ of oxalate respectively.

Table2. Effect of foreign ions in presence of $U(V I) .[U(V I)]=4.76 \mu g / m l$

\begin{tabular}{|l|l|l|l|}
\hline Anion & $\begin{array}{l}\text { Tolerance limit } \\
(\mu \mathrm{g} / \mathrm{ml})\end{array}$ & Cation & $\begin{array}{l}\text { Tolerance limit } \\
(\mu \mathrm{g} / \mathrm{ml})\end{array}$ \\
\hline Iodide & 1392 & $\mathrm{~K}(\mathrm{I})$ & 557 \\
\hline Phosphate & 1212 & $\mathrm{Th}(\mathrm{IV})$ & 464 \\
\hline Bromide & 800 & $\mathrm{~W}(\mathrm{VI})$ & 185 \\
\hline Nitrate & 620 & $\mathrm{Al}(\mathrm{III})$ & 135 \\
\hline Sulphate & 384 & $\mathrm{Cd}(\mathrm{II})$ & 112 \\
\hline Thiourea & 380 & $\mathrm{Ba}(\mathrm{II})$ & 55 \\
\hline Carbonate & 300 & $\mathrm{Co}(\mathrm{II})$ & 35 \\
\hline Farmate & 270 & $\mathrm{Ni}(\mathrm{II})$ & 29 \\
\hline Oxalate & 250 & $\mathrm{Cu}(\mathrm{II})$ & $36^{\mathrm{a}}$ \\
\hline Thiosulphate & 235 & $\mathrm{Mo}(\mathrm{VI})$ & $175^{\mathrm{b}}$ \\
\hline Fluoride & 177 & $\mathrm{Cr}(\mathrm{VI})$ & $120^{\mathrm{c}}$ \\
\hline Chloride & 175 & $\mathrm{Mn}(\mathrm{II})$ & 11 \\
\hline Tartrate & 150 & $\mathrm{~V}(\mathrm{~V})$ & 9 \\
\hline Acetate & 120 & $\mathrm{Zn}(\mathrm{II})$ & 5 \\
\hline EDTA & $\mathrm{Interferes}$ & $\mathrm{Zr}(\mathrm{IV})$ & 5 \\
\hline & & $\mathrm{Hg}(\mathrm{II})$ & pricipitate \\
\hline
\end{tabular}

${ }^{a}$ Avoided by masking with 400 ppm of oxalate

${ }^{b}$ In presence of 400 ppm of phosphate

${ }^{c}$ Avoided by masking with 200 ppm of tartrate 


\subsection{Application}

The present method is applied for the determination of U(VI) in biological and environmental samples. The analytical determination of uranium was carried out by the general experimental procedure mentioned in 2.2. The results presented in Table 3 indicate the applicability of the reported method.

Table3. Determination of uranium(VI) present in monazite sand, synthetic pitchblend ore, spiked water, human hair and human blood samples. $[3,4-D H B T S C]=8 \times 10^{-3} \mathrm{M}, \quad \mathrm{pH}=7, \lambda_{\max }=370 \mathrm{~nm}$;

\begin{tabular}{|l|c|c|c|}
\hline \multicolumn{1}{|c|}{ Sample } & $\begin{array}{c}\text { ICPAES/AAS/ICP-MS } \\
\text { U(VI) value in } \mu \mathrm{g} / \mathrm{ml}\end{array}$ & $\begin{array}{c}\text { Amount of U(VI) found } * \text { in } \mu \mathrm{g} / \mathrm{ml} \\
\text { By present method }\end{array}$ & Relative error (\%) \\
\hline Monazite sand & 3.03 & 2.95 & -2.71 \\
\hline Synthetic pitchblend ore & 12.5 & 12.4 & -0.80 \\
\hline Spiked tap water & 50 & 49.5 & -1.01 \\
\hline Spiked waste water & 100 & 99.4 & -0.60 \\
\hline Spiked well water & 200 & 202 & +0.99 \\
\hline $\begin{array}{l}\text { Human hair of cancer } \\
\text { patient }\end{array}$ & 0.36 & 0.35 & -2.85 \\
\hline $\begin{array}{l}\text { Human blood of } \\
\text { leukemia patient }\end{array}$ & 2.89 & 2.90 & +0.34 \\
\hline
\end{tabular}

*Average of three determinations.

*The value of $t$ at $95 \%$ confidence level is 50.60

\section{REFERENCES}

[1] Lutfullah, Farheen Khan, Nafisur Rahman and Syed Najmul Hejaz Hazmi. (2009) Indian Journal of Chemical Technology 16, 437-441.

[2] Chan-il Park, Hua-Zi Huang, and Ki-Won Cha. (2001) Bull. Korean Chem. Soc. 22, 1-3

[3] G.H.Rizvi. (1986) J.Radioanal.Nucl.Chem 5, 309-317.

[4] M.Madbouly, M.H.Nassef, A.M.Diab and S.A.El-Mongy. (2009) Journal Nuclear and Radiation Physics 4, 75-81.

[5] U.J.Chukwu and J.Godwin. (2013) American Chemical Science Journal 4, 479-488.

[6] H.Salar Amoli and J.Barker. (2007) Chem.Anal.(Warsaw) 52, 35-42.

[7] I.H.Saleh and A.A. Abdel-Halim. (2016) Journal Taibah University for Science 10, 205-211.

[8] Ngo Quang Huy, Trinh Thi Bich and Nguyen Van Suc. (2006) Journal Radioanalytical and Nuclear Chemistry 269, 129-133.

[9] M.B.Rajkovik, Gordana Pantelic and Irena petrovic. (2001) Journal of Agricultural sciences 46, 163-174.

[10] Satya Sebastian, P. U.Singare and R. S.Lokhande. (2013) International Letters of Chemistry, Physics and Astronomy 12, 125-133.

[11] Leonardo Sena Gomes Teixeira, Antonio Celso Spínola Costa and Sérgio Luís Costa Ferreira. (1999) Journal of the Brazilian Chemical Society 10, 90-103.

[12] M. KonstAntinou and I. Pashalidis. (2004) Mediterranian Material Science 5, 55-60.

[13] Tariq M.Bhatti, Abdul Mateen, M.Amin,Kauser, A.Malik and Ahmad M. Khalid. (1991) Journal of Chemical Technology and Biotechnology 52, 331-341.

[14] J.Krtil, V.Kuvik and V.Spivackova. (1984) J.Radioanal.Nucl.Chem.Letters 3, 161-170.

[15] Mamoune El Himri, Agustín Pastor and Miguel de la Guardia. (1999) Fresenius J Anal Chem 367, 151-156.

[16] Jaison PG, Telmore VM, Kumar P and Aggarwal SK. (2001) J Chromatoqr Sci 9, 657-664.

[17] Yoshida S, Muramatsu Y and Tagami K. (2001) Environ Sci Technol 21, 4174-4179.

[18] Hoshino M, Matsushita M, Samma M, Asano M, Yamaguchi T and Fujita Y. (2011) Chem Pharm Bull 6, 721-725. 